\title{
Implicações do Recurso Extraordinário 1.231.883 e das Teses de Repercussão Geral 157 e 835: uma análise da competência dos Tribunais de Contas
}

Implications of Extraordinary Resources 1,231,883 and General Repercussion Theses 157 and 835: an analysis of the Court of Auditors' competence

\section{Lucas Araújo Meneses ${ }^{1}$ João Marcelo Pereira Fortinho de Miranda Sá ${ }^{2}$}

\section{RESUMO}

O presente artigo tem como escopo a análise das implicações da decisão monocrática do Recurso Extraordinário $\mathrm{n}^{\circ} 1.231 .883$ e das teses de Repercussão Geral 157 e 835 ao controle externo exercido pelos Tribunais de Contas quanto às prestações de contas de gestão de Prefeitos que atuam como ordenadores de despesas. Desse modo, realizou-se levantamento bibliográfico, jurisprudencial e doutrinário acerca da problemática da competência das Cortes de Contas para julgar as prestações de contas de gestão nesse caso, no qual se ressalvou os efeitos deletérios à Administração Pública de tais decisórios do Supremo Tribunal Federal, haja vista o julgamento de cunho político e ineficaz da Câmara Municipal. Por fim, conclui-se que o entendimento da Corte Suprema não merece prosperar, visto que obsta e enfraquece o controle externo de tais tribunais.

Palavras-Chave: Competência. Tribunal de Contas. Prefeito. Julgamento Político. Controle Externo.

\footnotetext{
$1 \quad$ Graduando em Direito pela Universidade Federal do Ceará. E-mail: lucasmnss931@gmail.com 2 Pós-graduando em Direito Tributário pelo Instituto Brasileiro de Estudos Tributários. E-mail: jmarcelomiranda@hotmail.com
} 


\section{ABSTRACT}

The purpose of this paper is to analyze the conclusions of the monocratic decision of Extraordinary Appeal No. 1,231,883 and the Theses of General Repercussion 157 and 835 to the external control exercised by the Courts of Accounts regarding the rendering of mayors' management accounts that act as ordinators expenses. Thus, a bibliographic, jurisprudential and doctrinal survey was carried out on the issue of the competence of the Courts of Accounts to judge as rendering of management accounts in this case, where the deleterious effects on the Public Administration of such decisions of the Supreme Federal Court were noted, given the political and ineffective judgment of the City Council. Finally, it is concluded that the Supreme Court's understanding does not deserve to prosper, since it hinders and weakens the external control of such courts.

Keywords: Competence. Audit Office. Politic Judgment. Mayor. External Control.

Recebido: 11-08-2020

Aprovado: 07-10-2020

\section{INTRODUÇÃO}

$\mathrm{Na}$ Antiguidade Clássica os cidadãos realizavam reuniões em praça pública para discutir acerca das relações políticas e sociais da cidade, como na Ágora ateniense. Analogamente, o papel desempenhado pelas Câmaras Municipais e pelos Tribunais de Contas na apreciação e julgamento das prestações de contas de governo e de gestão é essencial ao probo gerenciamento da coisa pública pelo Chefe do Poder Executivo Municipal. Todavia, ainda reverberam no meio jurídico problemáticas de repercussão geral relacionadas ao papel e ao desempenho das atividades dos Tribunais de Contas e da Câmara Municipal, principalmente quanto aos processos de prestação de contas de responsabilidade de Alcaides, 
havendo frequentes discussões travadas entre doutrinadores e estudiosos do direito público e gestão municipal.

O presente trabalho tem como escopo a análise das implicações da decisão proferida no Recurso Extraordinário $n^{0} 1.231 .883$, do Ceará, do Supremo Tribunal Federal (STF), o qual ainda encontra-se em tramitação. Já havendo o relator Ministro Luiz Fux decidido, monocraticamente, no dia 7 de outubro de 2010, que apesar de as consequências de ordem civil e administrativa decorrentes de eventuais irregularidades cometidas pelos Prefeitos na ordenação de despesas independerem de deliberação das Câmaras Municipais, tais consequências não podem ser impostas, de forma direta, pelos Tribunais de Contas, de modo que para tanto há a necessidade de manejo das ações judiciais próprias.

Neste jaez, apesar da supramencionada existência de divergências doutrinárias e na aplicação das normas referentes ao controle externo no que diz respeito ao julgamento de contas de Prefeitos pelos diversos Tribunais de Contas brasileiros, a decisão do Recurso Extraordinário 1.231.883, do Ceará, reafirma os Recursos Extraordinários n ${ }^{\circ} 848.826$, do Distrito Federal e $n^{0} 729.744$, de Minas Gerais. Por isso, o presente artigo fará também uma análise conjunta dos referidos Recursos Extraordinários, bem como do arcabouço doutrinário, jurisprudencial e constitucional da distinção dos órgãos competentes para julgar as contas públicas dos Prefeitos que exercem a função de ordenadores de despesas, sendo tal discussão de fundamental importância, haja vista que esta situação é bastante comum em municípios de menor porte econômico.

Isto posto, empreende-se preliminarmente a importância dessa pesquisa para toda a coletividade social e jurídica, certo que a temática trata do gerenciamento dos gastos públicos realizados por Prefeitos enquanto ordenadores de despesas e chefes do executivo municipal, bem como da realização de forma efetiva do controle externo pelas Cortes de Contas, dentro dos parâmetros constitucionais.

Por fim, vê-se, ainda, que a notoriedade da problemática a ser trata- 
da não se exauriu, haja vista as divergências e os debates travados no âmbito dos Tribunais de Contas pátrios e a existência de processo em trâmite no âmbito do Supremo Tribunal Federal. Assim, justamente por isso, a análise das implicações das decisões da Corte Constitucional nos Recursos Extraordinários é de extrema relevância para o exercício efetivo da democracia e do controle externo.

\section{O TRIBUNAL DE CONTAS E A CONSTITUIÇÃO DE 1988}

A Constituição Federal de 1988 restabeleceu o Estado Democrático de Direito brasileiro e fortaleceu as instituições de controle externo, visto que estas são essenciais para manutenção da Administração Pública. Para isso, a "Constituição-Cidadã" ampliou o rol de competências institucionais do Tribunal de Contas da União e, consequentemente, dos Tribunais de Contas Estaduais e Municipais. Deste modo, a atuação dos Tribunais de Contas foi aperfeiçoada para atender ao Estado que se reerguia após o Regime Militar de 1964, o que proporcionou uma atuação mais eficiente e ativa no controle externo dos recursos públicos.

Sob este viés, a vasta quantidade de correntes de pensamento na Assembleia Nacional Constituinte é resultado de décadas de aperfeiçoamento doutrinário e legal, inclusive, de outros países. Dessa forma, o trabalho do Constituinte fora de extrema importância, haja vista a escolha da teoria que melhor atendesse o interesse público. Assim sendo, a Constituição de 1988 acompanhou a moderna teoria do controle externo, como ocorre nas principais Constituições democráticas da modernidade, como a Constituição da Itália de 1947, a Constituição da Espanha de 1978 e a Constituição Alemã de 1949. Logo, a adoção da teoria moderna do controle externo pelo Constituinte contribuiu para o aumento das prerrogativas dos Tribunais de Contas e para a efetivação de suas importantes funções.

Cabe destacar também que o constitucionalismo moderno, a conso- 
lidação do Estado Democrático e a cidadania contribuíram para a construção do Tribunal de Contas conforme ensejado por Rui Barbosa. A função de fiscalizar o gerenciamento dos recursos públicos e assegurar a correta aplicação e arrecadação reafirma os princípios da legalidade, economia e legitimidade, os quais guiam a atuação dos Tribunais de Contas pátrios. Sendo assim, o controle das finanças públicas nos moldes da Constituição de 1988, exercido pelos Tribunais de Contas, garantem e asseveram os direitos individuais e coletivos.

Segundo Mata (1994), entende-se por economicidade a tentativa de empregar de forma eficiente a mínima quantidade de recursos e esforços da máquina pública para conseguir os resultados almejados. Tal princípio, expresso no artigo 70 da Constituição Federal de 1988, preza pela obtenção do resultado, mantendo a qualidade, com o menor custo possível. Já o princípio da legitimidade preza pela existência de conformação do ato com a lei vigente, isto é, com a ordem jurídica, bem como com o interesse coletivo e com a finalidade pública.

Por outro lado, o princípio da legalidade, conforme Mello (2005), é um cânone basilar da Administração Pública, visto que a Administração só pode agir mediante previsão legal anteriormente posta. Logo, só há de se fazer o que a lei expressamente permite. Desse modo, a atuação do Tribunal de Contas no controle externo norteia-se a partir destes princípios.

A Constituição Federal de 1988 refere-se ao controle externo no artigo 71, ficando este a cargo do Congresso Nacional, isto é, a um órgão do poder legislativo, e será exercido com o auxílio do Tribunal de Contas. O referido normativo vigora nos seguintes termos: "Art. 71. O controle externo, a cargo do Congresso Nacional, será exercido com o auxílio do Tribunal de Contas da União, ao qual compete".

Neste jaez, o controle externo refere-se a instrumento do Estado, por meio do qual instituições governamentais fiscalizam outros órgãos estatais a fim de assegurar o probo gerenciamento, aplicação e captação 
dos recursos públicos. No Brasil, o controle externo é atribuição do Poder Legislativo, o qual complementa-se com o auxílio do Tribunal de Contas para realizar fiscalizações financeiras, contábeis e patrimoniais em todos os órgãos dos três poderes constituintes da república brasileira, isto é, o Judiciário, o Executivo e o próprio Legislativo.

Sob este viés, o controle externo é uma forma de controle político de legalidade contábil e financeira, com vistas a comprovar a regularidade dos atos realizados pela Administração, seja nos empregos dos bens, valores e ou dinheiros públicos, bem como a fiel execução do orçamento público (MEIRELLES, 2001). Cabe destacar que o controle externo exercido pelos Tribunais de Contas difere do exercido pelo Legislativo, uma vez que este é técnico e especializado, não vinculado à ideologia política e/ou partidária. Empreende-se, pois, que o Tribunal de Contas é o órgão do Estado que mais se assemelha ao controle fiscalizador, haja vista suas prerrogativas constitucionais e sua independência e autonomia dos outros três poderes.

Isto posto, tem-se que o Tribunal de Contas é instituição essencial para a garantia dos valores democráticos e republicanos. Certo que sua função, conforme Costa (2006), garante o gerenciamento eficaz dos recursos públicos, bem como contribui para a transparência pública ao fiscalizar os representantes do povo quanto a aplicação de recursos. Todavia, recentes decisões decorrentes de reanálises constitucionais têm mitigado a atuação dos Tribunais de Contas no que tange ao julgamento e a apreciação de contas de gestão dos Chefes do Executivo Municipal quando estes são ordenadores de despesas, fato que ocorre, especialmente, em Municípios com menor aporte econômico. 


\section{A ATUAÇÃO DOS TRIBUNAIS DE CONTAS: A FUNÇÃO JULGADORA E A FUNÇÃO AUXILIAR}

Neste tópico será analisada a competência dos Tribunais de Contas Pátrios e a forma como se dá o desempenho de suas funções dentro dos limites constitucionais, sempre tendo em vista o aspecto histórico na criação das Cortes de Contas, as delimitações impostas pelo Poder Constituinte Originário quando da elaboração da Carta Magna e a função dúplice das referidas cortes. Sendo a primeira na atuação como julgadora de contas de gestores que exercem função de ordenadores de despesas e a função auxiliar para emitir parecer técnico prévio ao julgamento das contas do Chefe do Poder Executivo, em suas diferentes esferas, quando do julgamento das referidas contas pelo Poder Legislativo Municipal.

Assim, a Constituinte da Carta Magna de 1988 previu de forma expressa a existência e os atos de competências das Cortes de Contas, no Título IV - Da Organização dos Poderes, Capítulo I - Do Poder Legislativo, Seção IX - Da Fiscalização Contábil, Financeira e Orçamentária, especificamente nos Art. 71 e seguintes, senão vejamos:

Art. 71. O controle externo, a cargo do Congresso Nacional, será exercido com o auxílio do Tribunal de Contas da União, ao qual compete:

I - apreciar as contas prestadas anualmente pelo Presidente da República, mediante parecer prévio que deverá ser elaborado em sessenta dias a contar de seu recebimento;

II - julgar as contas dos administradores e demais responsáveis por dinheiros, bens e valores públicos da administração direta e indireta, incluídas as fundações e sociedades instituídas e mantidas pelo Poder Público federal, e as contas daqueles que derem causa a perda, extravio ou outra irregularidade de que resulte prejuízo ao erário público;

III - apreciar, para fins de registro, a legalidade dos atos de admissão de pessoal, a qualquer título, na administração direta e indireta, incluídas as fundações instituídas e mantidas pelo Poder Público, excetuadas as nomeações para cargo de provimen- 
to em comissão, bem como a das concessões de aposentadorias, reformas e pensões, ressalvadas as melhorias posteriores que não alterem o fundamento legal do ato concessório;

IV - realizar, por iniciativa própria, da Câmara dos Deputados, do Senado Federal, de Comissão técnica ou de inquérito, inspeções e auditorias de natureza contábil, financeira, orçamentária, operacional e patrimonial, nas unidades administrativas dos Poderes Legislativo, Executivo e Judiciário, e demais entidades referidas no inciso II;

$\mathrm{V}$ - fiscalizar as contas nacionais das empresas supranacionais de cujo capital social a União participe, de forma direta ou indireta, nos termos do tratado constitutivo;

VI - fiscalizar a aplicação de quaisquer recursos repassados pela União mediante convênio, acordo, ajuste ou outros instrumentos congêneres, a Estado, ao Distrito Federal ou a Município;

VII - prestar as informações solicitadas pelo Congresso Nacional, por qualquer de suas Casas, ou por qualquer das respectivas Comissões, sobre a fiscalização contábil, financeira, orçamentária, operacional e patrimonial e sobre resultados de auditorias e inspeções realizadas;

VIII - aplicar aos responsáveis, em caso de ilegalidade de despesa ou irregularidade de contas, as sanções previstas em lei, que estabelecerá, entre outras cominações, multa proporcional ao dano causado ao erário;

IX - assinar prazo para que o órgão ou entidade adote as providências necessárias ao exato cumprimento da lei, se verificada ilegalidade;

$\mathrm{X}$ - sustar, se não atendido, a execução do ato impugnado, comunicando a decisão à Câmara dos Deputados e ao Senado Federal;

XI - representar ao Poder competente sobre irregularidades ou abusos apurados.

Apesar de a previsão dos atos de competência dos Tribunais de Contas Pátrios estarem previstas no mesmo Capítulo I, do Título IV, da Constituição Federal de 1988 que trata do Poder Legislativo, entende-se que as Cortes de Contas são órgãos autônomos, com independência financeira e administrativa, que quando do desempenho de parte de suas 
atribuições funciona como auxiliar do Poder Legislativo para julgamento das contas do Chefe do Poder Executivo, atuando como órgão técnico consultivo. Posto isto, esclarece Jacoby (2005) que é necessário realizar tal ressalva quanto à função jurisdicional, com vistas a possibilitar a observação dos Tribunais de Contas como órgão autônomo e independente do Poder Legislativo, consoante se verá de forma pormenorizada adiante.

Desta feita, conforme depreende-se da análise do Art. 71 e seguintes da Constituição da República, diversas são as funções dos Tribunais de Contas, daí sua relevância e importância para o escorreito funcionamento da máquina pública, do equilíbrio nas gestões públicas e sobretudo na separação dos três poderes, viabilizando a realização do chamado sistema de freios e contrapesos.

Antes de adentrar especificamente nas atribuições dos Tribunais de Contas, é importante realizar breve abordagem acerca do dever de prestar contas, tendo este sido conceituado de forma plena pela Constituição Federal, no Parágrafo Único do Art. 70, in verbis:

\footnotetext{
Art. 70. A fiscalização contábil, financeira, orçamentária, operacional e patrimonial da União e das entidades da administração direta e indireta, quanto à legalidade, legitimidade, economicidade, aplicação das subvenções e renúncia de receitas, será exercida pelo Congresso Nacional, mediante controle externo, e pelo sistema de controle interno de cada Poder.

Parágrafo único. Prestará contas qualquer pessoa física ou jurídica, pública ou privada, que utilize, arrecade, guarde, gerencie ou administre dinheiros, bens e valores públicos ou pelos quais a União responda, ou que, em nome desta, assuma obrigações de natureza pecuniária (Redação dada pela Emenda Constitucional $n^{\circ} 19$, de 1998).
}

Portanto, vê-se que qualquer pessoa física ou jurídica que faça uso, de forma ampla, de qualquer verba pública, tem a obrigação de prestar contas, ficando a análise técnica e a realização de tal controle a cargo dos Tribunais de Contas pátrios, nesse sentido ensina Celso Antônio Bandeira de Mello (1984, p. 136): 
a missão de efetuar um apurado controle sobre a legitimidade dos atos administrativos conducentes à despesa pública é, obviamente, uma missão teórica - técnico-jurídica e, portanto, dificilmente poderia ser desempenhada a contento por um corpo legislativo, sem que contasse com o auxílio de um organismo especializado ao qual incumba esta apreciação técnica, que irá iluminar a posterior decisão política do legislativo na apreciação da gestão dos recursos públicos.

Pois bem, demonstrada a relevância e rememorado o conceito de controle externo, nos termos já expostos no capítulo anterior, passemos à análise das formas de atuação dos Tribunais de Contas, tendo sempre em mente a delimitação optada para a realização do presente estudo científico, qual seja: o julgamento pelos Tribunais de Contas de contas prestadas por gestores públicos, especificamente por Prefeitos Municipais.

Aqui faz-se necessário destacar que, além do Tribunal de Contas da União, responsável por julgar contas que envolvam verbas oriundas da União, nos termos do Art. $1^{\circ}$, inciso I, da Lei Federal $n^{\circ} 8.443$, de 16 de julho de 1992, cada ente federativo possui autonomia para elaboração de sua Constituição Estadual e, consequentemente, para criação do Órgão responsável pela realização do controle externo no âmbito estadual, desde que respeitado o Princípio da Simetria Constitucional, devendo ser mantida coerência e uma relação simétrica entre os institutos jurídicos das Constituições Estaduais para com a Constituição Federal.

Todos os Estados possuem um Tribunal de Contas Estadual, havendo em alguns deles a existência também de Tribunais de Contas dos $\mathrm{Mu}-$ nicípios do Estado, sendo estes órgãos estaduais competentes para julgar contas oriundas dos municípios de determinado estado, como nos estados da Bahia, Goiás e Pará. E, em apenas dois Estados, há Tribunal de Contas do Município, sendo este órgão municipal competente para julgar contas de um município específico, como é o caso do Tribunal de Contas do Município de São Paulo e do Tribunal de Contas do Município do Rio de 
Janeiro, criados respectivamente em 1968 e 1980. A existência de apenas dois Tribunais de Contas do Município em todo território nacional se dá porque a Constituição Federal de 1988, em seu Art. $31, \S 4^{\circ}$, vetou a criação de novos Tribunais, Conselhos ou órgãos de Contas Municipais.

Desta feita, a análise das contas prestadas por gestores públicos no âmbito do Poder Executivo, na efetivação do controle externo, pode se dar em duas seguintes hipóteses: nas prestações de contas de governo prestadas pelos Chefes do Poder Executivo, seja ele em âmbito Municipal, ficando a cargo dos Prefeitos Municipais, Estadual, de responsabilidade dos Governadores de Estado e, no âmbito Federal, a cargo do Presidente da república; e nas prestações de contas de gestão, sendo estas de responsabilidade dos gestores das pastas integrantes do Poder Executivo em determinada instância, sendo ambas prestadas de forma anual pelo responsável.

As distinções entre os processos de prestação de contas de governo e o processo de prestação de contas de gestão são inúmeras. Jacoby (2012) entende que tais diferenças partem desde as partes integrantes da referida prestação de contas até a forma como se dará a análise desta por parte do Tribunal de Contas competente. Segundo a Lei Orgânica do Tribunal de Contas do Estado do Ceará, a prestação de contas de governo, seja ela do Governador do Estado ou dos Prefeitos Municipais, deverá conter o balanço geral da gestão, incluindo as diversas pastas do ente federado, além de relatórios e demonstrações da execução orçamentária programada no início da gestão, destacando ainda que estas serão analisadas pela Corte através da emissão de parecer prévio que será encaminhado à Assembleia Legislativa ou à Câmara Municipal, a depender da autoridade responsável, senão veja:

Art. 42 Ao Tribunal de Contas do Estado, órgão de Controle Externo, compete apreciar as contas prestadas anualmente pelo Governador do Estado, mediante parecer prévio, a ser elaborado em 60 (sessenta) dias, a contar do seu recebimento, que será encaminhado à Assembleia Legislativa e ao Governador do Estado. 
$\S 1^{\circ}$ A decisão decretada pela Assembleia Legislativa será conclusiva, não cabendo mais qualquer apreciação por parte do Tribunal de Contas.

$\S 2^{\circ}$ As contas consistirão nos balanços gerais do Estado e no relatório do órgão central do sistema de controle interno do Poder Executivo, sobre a execução dos orçamentos de que trata o $\S 3^{\circ}$ do Art. 203 da Constituição do Estado, contendo informações sobre as atividades inerentes aos Poderes Legislativo e Judiciário e ao Ministério Público, relativas à execução dos respectivos programas incluídos no orçamento anual e respectivas inspeções e auditorias internas.

Art. 42-A Ao Tribunal de Contas do Estado, órgão de Controle Externo, compete apreciar as contas prestadas anualmente pelo Prefeito, mediante parecer prévio, a ser elaborado em um ano, a contar do seu recebimento, que será encaminhado à Câmara Municipal e ao Prefeito. ${ }^{*}$ Dispositivo acrescido pelo Art. $1^{\circ}, \S$ 23, da Lei $n^{\circ}$. 16.819, de 08.01.2019 - D.O.E. 09.01.2019.

$\S 1^{\circ}$ A decisão decretada pela Câmara Municipal será conclusiva, não cabendo mais qualquer apreciação por parte do Tribunal de Contas. ${ }^{*}$ Dispositivo acrescido pelo Art. $1^{\circ}, \S 23$, da Lei $n^{\circ}$. 16.819, de 08.01.2019 - D.O.E. 09.01.2019.

$\S 2^{\circ}$ As contas consistirão nos balanços gerais do Município e no relatório de controle interno do Poder Executivo Municipal sobre a execução dos orçamentos de que trata o art. 165 da Constituição Federal, contendo informações relativas à execução dos respectivos programas incluídos no orçamento anual e respectivas inspeções e auditorias internas. *Dispositivo acrescido pelo Art. $1^{\circ}, \S 23$, da Lei $n^{\circ}$. 16.819, de 08.01.2019 - D.O.E. 09.01.2019.

Já quanto a prestação de contas de gestão, essas deverão estar acompanhadas de todos os relatórios de gestão e de todos os recursos orçamentários despendidos pela pasta. Sua análise será feita pela Corte de Contas Estadual através de julgamento em definitivo, pois é o que determina, por exemplo, a Lei Orgânica do Tribunal de Contas do Estado do Ceará (Lei 12.509/95), in verbis:

Art. $6^{\circ}$ Estão sujeitas à tomada de contas e, ressalvado o disposto no inciso XXXV do Art. $5^{\circ}$ da Constituição Federal, só por 
decisão do Tribunal de Contas do Estado podem ser liberadas dessa responsabilidade, as pessoas indicadas nos incisos I a VI do Art. $5^{\circ}$ desta Lei.

Art. $7^{\circ}$ As contas dos administradores e responsáveis a que se refere o Artigo anterior serão anualmente submetidas a julgamento do Tribunal, sob a forma de tomada ou prestação de contas.

$\S 1^{\circ}$ Nas tomadas ou prestações de contas, a que alude este Artigo, devem ser incluídos todos os recursos, orçamentários e extra-orçamentários, geridos ou não pela unidade ou entidade administrativa respectiva. [...]

Art. $9^{\circ}$ Integrarão a tomada ou prestação de contas, inclusive a tomada de contas especial, dentre outros elementos, os seguintes:

I - relatório de gestão, se for o caso;

II - relatório do tomador de contas, quando couber;

III - relatório e certificado de auditoria, com parecer do dirigente de controle interno, que consignará qualquer irregularidade ou ilegalidade constatada, indicando as medidas adotadas para corrigir as faltas encontradas;

$\mathrm{V}$ - pronunciamento do Secretário de Estado ou de Município supervisor da área ou da autoridade de nível hierárquico equivalente, na forma prevista no Art. 55 desta Lei (CEARÁ, 1995).

Acerca da diferença entre a prestação de contas de governo e a prestação de contas de gestão assim ensina Lima (2019, p. 92):

Assim, a partir das definições contidas na Resolução Normativa $n^{\circ}$ 10/2008 do TCE-MT, entende-se que as contas anuais de governo demonstram a conduta do Presidente, do Governador ou do Prefeito no exercício das funções políticas de planejamento, organização, direção e controle das políticas públicas; e as contas anuais de gestão evidenciam os atos de administração e gerência de recursos públicos praticados pelos administradores e demais responsáveis por dinheiros, bens e valores dos órgãos e entidades. De outro modo: as contas de governo propiciam uma avaliação "macro", de natureza política, verificando-se, por exemplo, se foram cumpridos os valores mínimos constitucionalmente previstos para aplicação em saúde e na manutenção e no desenvolvimento do ensino (CF: arts. 198, $\S \S 1^{\circ}, 2^{\circ} \mathrm{e}$ 


\section{Entrole}

$3^{\circ}$, e 212); já as contas de gestão proporcionam uma avaliação "micro", eminentemente técnica, examinando-se os aspectos da legalidade, legitimidade e economicidade ao nível de um determinado contrato ou ordem de pagamento.

Assim, conforme exarado anteriormente, a primeira principal diferença entre a prestação de contas de governo para a prestação de contas de gestão diz respeito à forma a qual esta é prestada, se de forma macro ou micro, sendo a segunda divergência entre elas a forma como se dará o julgamento destas. Haja vista que, enquanto nas contas de gestão o Tribunal de Contas é responsável por todo o processo, desde a instrução até o julgamento, nas contas de Governo a Corte de Contas funciona como órgão técnico responsável pela emissão de parecer prévio técnico, visando auxiliar o Poder Legislativo a realizar julgamento político das contas.

Acerca do processo de julgamento de contas de governo, assim ministra José Afonso da Silva (2004, p. 760):

O controle externo é, pois, função do Poder Legislativo, sendo de competência do Congresso Nacional no âmbito federal, das Assembleias Legislativas nos estados, da Câmara Legislativa no Distrito Federal e das Câmaras Municipais nos municípios com o auxílio dos respectivos Tribunais de Contas. Consiste, assim, na atuação da função fiscalizadora do povo, através de seus representantes, sobre a administração financeira e orçamentária. É, portanto, um controle de natureza política, no Brasil, mas sujeito à prévia apreciação técnico-administrativa do Tribunal de Contas competente, que, assim, se apresenta como órgão técnico, e suas decisões são administrativas, não jurisdicionais.

Assim, a sistemática de julgamento das contas de governo foi definida pelo Constituinte Originário como devendo ser precedida de duas fases: a emissão de parecer prévio pela Corte de Contas competente, seguida de julgamento político pelo Poder Legislativo de determinada instância, de modo que é imprescindível salientar que o parecer técnico emitido por 
aquele, no caso de contas de governo prestadas por Prefeitos Municipais, apenas pode deixar de prevalecer se por decisão de 2/3 da Câmara Municipal, nos termos do art. 31, § 2 , da Constituição Federal de 1988.

Todavia, a fim de pacificar o entendimento dos Tribunais de Contas, em 2018, a Associação dos Membros dos Tribunais de Contas do Brasil (ATRICON) recomendou aos Tribunais de Contas brasileiros, através da Resolução n 01/2018, a emissão de parecer prévio no processo de contas de gestão em que o Prefeito figure como ordenador de despesas e, também, acórdão de julgamento para os demais efeitos como imputação de débito e aplicação de multa.

Visto isso, os tribunais de contas dos estados do Maranhão, de Roraima, do Espírito Santo, do Rio Grande do Norte, de Rondônia, do Mato Grosso do Sul, de Minas Gerais, de Pernambuco, do Amazonas, de Santa Catarina, do Rio Grande do Sul, da Paraíba, de Sergipe, do Amapá, do Paraná, do Ceará, do Alagoas, do Acre e do Tocantins, além dos tribunais de contas dos municípios do estado de Goiás e do Pará, passaram a segregar as espécies de prestações de contas ao emitir parecer prévio para as contas de governo e acórdão para as contas de gestão.

Enquanto os tribunais de contas do estado do Mato Grosso, de São Paulo, do Rio de Janeiro, do Piauí, além dos tribunais de contas do município de São Paulo e do Rio de Janeiro, tão somente emitem parecer prévio, isto é, não segregam as prestações de contas de governo e de gestão.

Ocorre que, em virtude das Teses de Repercussão Geral 157 e 835, bem como da decisão monocrática do RE 1.231.883/CE, o período anterior ao Registro de Candidaturas de candidatos às eleições municipais de 2020 fora marcado pelo ajuizamento de ações anulatórias nas varas do fazendário público, com pedido de liminar pela anulação total dos acórdãos dos Tribunais de Contas, observando-se os decisórios do Supremo Tribunal Federal acerca da competência das Cortes de Contas para julgar e aplicar as consequências cíveis e administrativas aos prefeitos. 
A partir disso, urgem diversas consequências ao Controle Externo e à Administração Pública, certo que prefeitos que tiveram suas contas de gestão desaprovadas pelas Cortes de Contas terão seus pedidos de Registro de Candidatura deferidos perante a Justiça Eleitoral. Logo, a responsabilização, bem como eventuais prejuízos ao erário público decorrentes de irregularidades, serão eximidas desses ordenadores de despesas.

\section{ANÁLISE E IMPLICAÇÕES DO RECURSO EXTRAORDI- NÁRIO 1.231.883 E DAS TESES DE REPERCUSSÃO GERAL 157 E 835}

Neste capítulo serão abordadas, de forma teórica, as nuances do Recurso Extraordinário $n^{\circ} 1.231 .883 / \mathrm{CE}$, especificamente no que diz respeito às controvérsias e divergências acerca da interpretação das normas constitucionais e da jurisprudência do Supremo Tribunal Federal sobre a competência dos Tribunais de Contas para julgar contas de Prefeitos Municipais, bem como suas consequências práticas no âmbito dos processos de prestação de contas de gestão e tomadas de contas nas Cortes de Contas.

Sob esta perspectiva, os questionamentos e divergências existentes acerca desta problemática têm por base as razões recursais que alcançam os tribunais de segunda instância e a Corte Constitucional, como é o caso do Recurso Extraordinário $n^{\circ} 1.231 .883 / \mathrm{CE}$, o qual tramita no Supremo Tribunal Federal, já havendo sido prolatada decisão monocrática pelo julgador relator, Ministro Luiz Fux, a qual será abordada a seguir.

Sendo assim, as dissonâncias doutrinárias favorecem o surgimento de debates enriquecedores sobre a questão, tendo em vista não só a diversidade de pontos de análise, mas também a relevância da fixação do órgão competente para julgar contas de Prefeitos. Dessa forma, há dois posicionamentos majoritários defendidos pela doutrina e pela jurisprudência: o primeiro é de que as Cortes de Contas possuem competência para julgar 
as contas de Prefeitos quando estes atuarem na condição de gestores, os chamados ordenadores de despesas, nas contas de gestão. Mas apenas tem competência para emissão de parecer prévio quando da análise das contas de governo, as quais devem ser submetidas ao julgamento da Câmara de Vereadores para aprovação ou rejeição do referido parecer técnico, podendo este apenas ser rejeitado por dois terços dos votos do Legislativo Municipal (SILVA; BELLAN, 2011).

Enquanto a segunda corrente doutrinária e jurisprudencial defende que os Tribunais de Contas Pátrios apenas possuem competência para emissão de parecer prévio opinativo, sendo de competência da Câmara Municipal o efetivo julgamento das contas, sejam elas contas de gestão ou contas de governo. Filiados a tal corrente encontram-se autores como Afonso Gomes de Aguiar e Márcio Paiva de Aguiar (2003), que argumentam que o juiz natural dos Chefes do Poder Executivo é o Legislativo, por conta disso a sua atuação como ordenador de despesas não lhe obsta o cargo de Chefe do Poder Executivo municipal.

No entanto, tal entendimento leva em consideração somente a qualificação do gestor, desprezando outras nuances relevantes à temática. $\mathrm{O}$ Decreto-Lei no 200/1967, o qual dispõe sobre a organização da Administração Federal, estabelece diretrizes para a Reforma Administrativa e dá outras providências, aborda e caracteriza o ordenador de despesas no Art. $80, \S 1$, como a autoridade de cujos atos resultarem emissão de empenho, autorização de pagamento, suprimento ou dispêndio de recursos da União ou pela qual esta responda.

Além disso, o caput do Art. 80 estabelece que os órgãos de contabilidade tenham como responsável todo o ordenador da despesa, cuja responsabilidade exaurir-se-á após julgadas regulares todas as contas pelo Tribunal de Contas. Desse modo, por equiparação, empreende-se que as contas prestadas pelo ordenador de despesa deverão ser julgadas pela Corte de Contas. 
Assim, o ordenador de despesa deverá ter suas contas apreciadas e julgadas pelo Tribunal de Contas responsável, o qual exercerá sua função julgadora. Haja vista que ao transferir a competência de ordenar a despesa para o ordenador de despesa secundário ou derivado, o ordenador de despesa originário ou principal realiza delegação de poderes, bem como a descentralização administrativa, em conformidade com os arts. 11 e 12 do Decreto-Lei ${ }^{\circ}$ 200/67, in verbis:

Art. 11. A delegação de competência será utilizada como instrumento de descentralização administrativa, com o objetivo de assegurar maior rapidez e objetividade às decisões, situando-as na proximidade dos fatos, pessoas ou problemas a atender.

Art. 12. É facultado ao Presidente da República, aos Ministros de Estado e, em geral, às autoridades da Administração Federal delegar competência para a prática de atos administrativos, conforme se dispuser em regulamento. Parágrafo único. $\mathrm{O}$ ato de delegação indicará com precisão a autoridade delegante, a autoridade delegada e as atribuições objeto de delegação.

Ocorre que as figuras do ordenador de despesas secundárias e principais podem concentrar-se em uma única autoridade. Assim, conforme leciona Nunes (2011), os prefeitos municipais, além de exercerem o comando geral da administração (praticando atos de governo), também exercem, inadvertidamente, atos de execução, isto é, gerem a máquina pública nos seus pormenores administrativos como as secretarias e os fundos municipais.

Portanto, caso o Chefe do Poder Executivo não descentralize a administração, ao delegar a função de ordenador de despesas a terceiro, o prefeito atuará como ordenador de despesas principal e secundário, logo, deverá prestar duas contas completamente distintas cujos fins serão distintos também. Sendo o primeiro tipo a conta de governo, que terão um julgamento político a cargo do Poder Legislativo com auxílio do Tribunal de Contas, o qual realizará sua função auxiliar com a emissão de parecer 
prévio opinativo. Enquanto o segundo tipo de conta do Chefe do Executivo ordenador de despesas será a conta de gestão, que terá um julgamento técnico e independente do Tribunal de Contas no exercício de sua função julgadora prevista no texto constitucional de 1988.

Dessa forma, quando o prefeito do município pratica os atos de Chefe do Executivo Municipal e, cumulativamente, a ordenação de despesas das pastas nos pormenores da administração pública, esse deve prestar contas as quais serão apreciadas e julgadas pelos Tribunais de Contas pátrios. Certo que a qualidade de ocupar cargo político não exime o prefeito da responsabilidade de prestar contas, nem tampouco do julgamento técnico da Corte de Contas.

Com efeito, o Alcaide submeter-se-á nesses casos a julgamento político das contas de governo pela Câmara Municipal e a julgamento técnico das contas de gestão pelo Tribunal de Contas responsável. Caso contrário, conforme preconiza Furtado (2007), bastaria o prefeito acumular as funções atribuídas, por meio da descentralização administrativa, aos ordenadores de despesas que restaria prejudicada uma das mais importantes competências institucionais do Tribunal de Contas, qual seja a de julgar as contas dos administradores e demais responsáveis por recursos públicos.

Sob esse viés, a ausência de julgamento pelas Cortes de Contas inviabiliza a possibilidade de reparação ao erário público pelo dano patrimonial causado pelo prefeito ordenador de despesas. A decisão monocrática do RE 1.231.883/CE reitera as Teses de Repercussão Geral 157 e 835 e obsta a aplicação de sanções administrativas e cíveis como a multa e a imputação de débito, certo da necessidade de manejo das ações judiciais próprias.

Visto isto, Fernandes (1991) reitera que a não sujeição dos prefeitos, quando estes atuam também como ordenadores de despesas, ao julgamento técnico pelos Tribunais de Contas das contas de gestão, significa a impossibilidade de responsabilização por tais despesas, logo, a isenção 
da responsabilidade ao prefeito que atua como ordenador de despesas é prejudicial ao probo gerenciamento da administração.

Por outro lado, o Supremo Tribunal Federal, nos autos do Recurso Extraordinário $n^{\circ} 848.826 / C E$, julgado no rito da repercussão geral, ao analisar os art. $31, \S 2^{\circ}$ e o art. 71, I e II, da Constituição Federal de 1988, fixou a seguinte Tese Jurídica de Repercussão Geral n ${ }^{\circ} 835$ :

Para os fins do art. $1^{\circ}$, inciso I, alínea "g", da Lei Complementar 64, de 18 de maio de 1990, alterado pela Lei Complementar 135, de 4 de junho de 2010, a apreciacão das contas de prefeitos, tanto as de governo quanto as de gestão, será exercida pelas Câmaras Municipais, com o auxílio dos Tribunais de Contas competentes, cujo parecer prévio somente deixará de prevalecer por decisão de $2 / 3$ dos vereadores.

Neste sentido, foi o julgamento do referido Recurso Extraordinário $\mathrm{n}^{\circ}$ 848.826/CE, de relatoria do Ministro Ricardo Lewandowski:

RECURSO EXTRAORDINÁRIO. PRESTACÃ̃O DE CONTAS DO CHEFE DO PODER EXECUTIVO MUNICIPAL. PARECER PRÉVIO DO TRIBUNAL DE CONTAS. EFICÁCIA SUJEITA AO CRIVO PARLAMENTAR. COMPETÊNCIA DA CÂMARA MUNICIPAL PARA O JULGAMENTO DAS CONTAS DE GOVERNO E DE GESTÃO. LEI COMPLEMENTAR 64/1990, ALTERADA PELA LEI COMPLEMENTAR 135/2010. INELEGIBILIDADE. DECISÃO IRRECORRÍVEL. ATRIBUIÇÃO DO LEGISLATIVO LOCAL. RECURSO EXTRAORDINÁRIO CONHECIDO E PROVIDO. I-COMPETE à Câmara Municipal o julgamento das contas do chefe do Poder Executivo municipal, com o auxílio dos Tribunais de Contas, que emitirão parecer prévio, cuja eficácia impositiva subsiste e somente deixará de prevalecer por decisão de dois tercos dos membros da casa legislativa (CF, art. 31, \& $2^{\circ}$ ). II - O Constituinte de 1988 optou por atribuir, indistintamente, 0 julgamento de todas as contas de responsabilidade dos prefeitos municipais aos vereadores, em respeito à relacão de equilíbrio que deve existir entre os Poderes da República 
(“checks and balances”). III - A Constituição Federal revela que o órgão competente para lavrar a decisão irrecorrível a que faz referência o art. $1^{\circ}$, I, g, da LC 64/1990, dada pela LC 135/ 2010, é a Câmara Municipal, e não o Tribunal de Contas. IV Tese adotada pelo Plenário da Corte: "Para fins do art. $1^{\circ}$, inciso I, alínea g, da Lei Complementar 64, de 18 de maio de 1990, alterado pela Lei Complementar 135, de 4 de junho de 2010, a apreciação das contas de prefeito, tanto as de governo quanto as de gestão, será exercida pelas Câmaras Municipais, com o auxílio dos Tribunais de Contas competentes, cujo parecer prévio somente deixará de prevalecer por decisão de $2 / 3$ dos vereadores". V - Recurso extraordinário conhecido e provido (RE 848826, Relator(a): Min. ROBERTO BARROSO, Relator(a) p/ Acórdão: Min. RICARDO LEWANDOWSKI, Tribunal Pleno, julgado em 10/08/2016, ACÓRDÃO ELETRÔNICO REPERCUSSÃO GERAL - MÉRITO DJe-187 DIVULG 23-08-2017 PUBLIC 24-08-2017).

Além disso, fora fixada a Tese Jurídica de Repercussão Geral de $\mathrm{n}^{\circ}$ 157, a qual define a natureza do parecer técnico com meramente opinativa, in verbis:

O parecer técnico elaborado pelo Tribunal de Contas tem natureza meramente opinativa, competindo exclusivamente à Câmara de Vereadores o julgamento das contas anuais do Chefe do Poder Executivo local, sendo incabível o julgamento ficto das contas por decurso de prazo.

Vejamos, ainda, o Acórdão que serviu de supedâneo para a fixação da tese acima mencionada:

Repercussão Geral. Recurso extraordinário representativo da controvérsia. 1. Competência da Câmara Municipal para julgamento das contas anuais de prefeito. 2. Parecer técnico emitido pelo Tribunal de Contas. Natureza jurídica opinativa. 3. Cabe exclusivamente ao Poder Legislativo o julgamento das contas anuais do chefe do Poder Executivo municipal. 4. Julgamento ficto das contas por decurso de 
prazo. Impossibilidade. 5. Aprovação das contas pela Câmara Municipal. Afastamento apenas da inelegibilidade do prefeito. Possibilidade de responsabilização na via civil, criminal ou administrativa. 6. Recurso extraordinário não provido (RE 729744, Relator(a): Min. GILMAR MENDES, Tribunal Pleno, julgado em 10/08/2016, ACÓRDÃO ELETRÔNICO REPERCUSSÃO GERAL - MÉRITO DJe-186 DIVULG 22-08-2017 PUBLIC 23-08-2017).

Desta feita, percebe-se que o posicionamento do Supremo Tribunal Federal se encontra no sentido de que somente cabe ao Poder Legislativo o julgamento das contas dos Alcaides e não às Cortes de Contas. Entretanto, a discussão acerca da competência para tanto não restou pacificada apesar de tais julgados, pois parte da doutrina e dos magistrados das Cortes de Contas e da Justiça comum defendem que a Tese Jurídica de Repercussão Geral $n^{\circ} 835$ fixou a incompetência dos Tribunais de Contas apenas para fins eleitorais, previstos no Art. $1^{\circ}$, inciso I, alínea g, da Lei Complementar $\mathrm{n}^{\circ} 64$ de 1990, não retirando sua competência para realizar o julgamento das contas em que os prefeitos atuem como ordenadores de despesas. Sendo exatamente essa controvérsia que teria ensejado a violação do Art. 71, I e II, da Constituição Federal, e dado ensejo à interposição do Recurso Extraordinário $\mathrm{n}^{\mathrm{o}}$ 1.231.883/CE, figurando nesse como Recorrente o Estado do Ceará e como Recorrido o Sr. Tertuliano Candido de Araújo.

No bojo do referido Recurso, como dito, defende a ProcuradoriaGeral do Estado do Ceará que o Supremo Tribunal Federal considerou as Câmaras de Vereadores como sendo competentes para julgar as contas de gestão de Prefeitos Municipais apenas no que diz respeito aos fins do Art. $1^{\circ}$, inciso I, alínea g, da Lei Complementar $n^{\circ} 64$ de 1990. Tendo sido mantida incólume a competência dos Tribunais de Contas para julgar a citada espécie de contas para todos os demais fins que não envolvam questões eleitorais, relativamente à fiscalização e aplicação de medidas cautelares e sanções contra os gestores públicos, incluindo os Chefes do Poder Executivo. 
Entretanto, a supramencionada tese da Procuradoria-Geral do Estado do Ceará não nos parece a mais acertada, tendo em vista as previsões normativas da Constituição da República. Nesse diapasão, temos no artigo 71, do texto constitucional que: "O controle Externo, a cargo do Congresso Nacional, será exercido com o auxílio do Tribunal de Contas da União, ao qual compete". Sendo complementado pelo inciso I, do mesmo artigo, onde descreve como competência do Tribunal de Contas da União: "I apreciar as contas prestadas anualmente pelo presidente da república, mediante parecer prévio que deverá ser elaborado em sessenta dias a contar do seu recebimento".

Analogamente, pelo princípio da simetria, entende-se que aos Tribunal de Contas Estaduais compete apreciar as contas prestadas anualmente pelos Prefeitos Municipais, sejam elas de gestão ou de governo, mediante parecer prévio a ser encaminhado para a Câmara Municipal, momento em que, aí sim, serão julgadas as contas de forma definitiva. Isto porque, em respeito ao princípio do juiz natural, insculpido no inciso LIII do artigo $5^{\circ}$ da Constituição Federal de 1988, o órgão competente para julgar as contas de Alcaides é o Poder Legislativo Municipal, conforme disposto no Art. 31, da Carta Magna:

Art. 31 - A fiscalização do Município será exercida pelo Poder Legislativo Municipal, mediante controle externo, e pelos sistemas de controle interno do Poder Executivo Municipal, na forma da lei.

$\S 1^{\circ}-\mathrm{O}$ controle externo da Câmara Municipal será exercido com o auxílio dos Tribunais de Contas de gestão dos Estados ou do Município ou dos Conselhos ou Tribunais de Contas de gestão dos Municípios, onde houver.

$\S 2^{\circ}-\mathrm{O}$ parecer prévio, emitido pelo órgão competente sobre as contas de gestão que o Prefeito deve anualmente prestar, só deixará de prevalecer por decisão de dois terços dos membros da Câmara Municipal.

Assim sendo, cabe destacar parte do Voto proferido pela Conselhei- 
ra Soraia Victor, membra do Tribunal de Contas do Estado do Ceará, no bojo do Processo $n^{\circ} 8310 / 11$, no qual fora exarado entendimento divergente ao aqui defendido, de que não possuem as Cortes de Conta competência para julgar as contas prestadas por Prefeitos Municipais, in verbis:

Inicialmente, registre-se que os presentes autos envolvem Prefeito atuando como ordenador de despesas, no entanto. em recente decisão, publicada em 24/08/2017, o STF definiu que os Tribunais de Contas não têm competência para julgar as contas de Prefeitos, mesmo quando agirem como ordenadores de despesa [...] não há como negar conhecimento à mencionada decisão da Suprema Corte, que me parece taxativa: a uma por ser fato público e notório, a duas porque já publicada oficialmente, a qual serve para orientação para todas as instâncias, qual seja, o Tribunal de Contas não tem competência para julgar Prefeitos, quando estes acumularem a condição de ordenadores de despesas. Isso significa incompetência absoluta, matéria de ordem pública, que deve ser declarada de ofício pelo julgador das contas. Como se vê, o Supremo eliminou o problema desde a raiz, ou seja, já definiu que o Prefeito não pode ser julgado no próprio processo administrativo das Cortes de Contas. A discussão central foi definir quem era o "órgão competente" para julgar as contas dos Prefeitos, se o TCE ou o Legislativo. [...] E a decisão foi expressa no sentido de que não importa a natureza das contas a serem prestadas (se de Gestão ou de Governo), mas sim o cargo de quem as presta, concluindo que compete exclusivamente ao Legislativo o julgamento de todas as contas de Prefeitos [...] Quanto à expressão "para fins da alínea g" é bem verdade que o Acórdão adotou esta expressão em seu conteúdo, o que pode levar a impressão que o decisium do STF só alcança a justiça eleitoral, e não os processos do TCE. Contudo, trata-se de ledo engano. Na realidade, citada expressão só foi incluída a pedido do Procurador Geral da República, Dr. Rodrigo Janot, apenas para salvar as ações Penais e de Improbidade, reconhecidas na via judicial [...] Portanto, a decisão a decisão do STF deixa a salvo as Ações penais e Ações de improbidade movidas pelo MP (alíneas "E" e "L"), o que era o único intuito da expressão "para fins da alínea G". Logo, referida expressão não deve ser confundida, porquanto a decisão é clara e expressa no 
tocante à definicão do único órgão competente para julgar as contas do Prefeito: a Câmara de Vereadores. [...] Vê-se, portanto, que o Acórdão do STF é claro e soberano em definir que as Cortes de Contas não podem julgar as contas dos Prefeitos. Ademais, não se sustenta 0 argumento de que a Decisão do supremo é restrita para efeitos eleitorais. Essa interpretação, data vênia, trata-se de um engano. [...] Desse modo, seja de modo forçoso ou por livre-convencimento, a apreciação das contas de Prefeito nesta Corte realmente só poderá ocorrer através de Parecer Prévio, em obediência à Decisão da Suprema Corte e de todo judiciário (TCE/CE - Proc. $\mathrm{n}^{\mathrm{o}}$ 8310/11. Relatora: Cons. Soraia Victor. Data do Julgamento: 27/03/2018).

Também neste sentido foi a decisão monocrática proferida pelo Ministro Luiz Fux, nos autos do Recurso Extraordinário no 1.231.883/CE, o qual segue pendente de ratificação ou reforma por decisão colegiada do Supremo Tribunal Federal em razão da interposição de Agravo Interno pelo Estado do Ceará, senão vejamos:

RECURSO EXTRAORDINÁRIO. CONSTITUCIONAL. ADMINISTRATIVO. COMPETE ÀS CÂMARAS MUNICIPAIS JULGAR AS CONTAS DE GOVERNO E DE GESTÃO DOS PREFEITOS - TEMA 835 DA REPERCUSSÃO GERAL. O PARECER PRÉVIO DO TRIBUNAL DE CONTAS QUE DESAPROVAAS CONTAS DO ALCAIDE NÃO PRODUZ EFEITOS ANTES DA DELIBERAÇÃO DA CÂMARA MUNICIPAL - TEMA 157 DA REPERCUSSÃO GERAL. TESES QUE NÃO SE RESTRINGEM À SEARA ELEITORAL NO QUE SE REFERE AOS TRIBUNAIS DE CONTAS. CONSEQUÊNCIAS DE ORDEM CIVIL E ADMINISTRATIVA ADVINDAS DE EVENTUAIS IRREGULARIDADES COMETIDAS PELOS PREFEITOS NA ORDENAÇÃO DE DESPESAS INDEPENDEM DE DELIBERAÇÃO DAS CÂMARAS MUNICIPAIS, MAS NÃO PODEM SER IMPOSTAS DIRETAMENTE PELOS TRIBUNAIS DE CONTAS, HAVENDO NECESSIDADE DE MANEJO DAS AÇÕES JUDICIAIS PRÓPRIAS. RECURSO DESPROVIDO (STF. RE $n^{\circ} 1.231 .883$ /CE. Relator: Min. Luiz Fux. Data do Julgamento: 07/10/2019). 
Por outro lado, apesar do entendimento jurisprudencial e dos ditames da Constituição Federal, é importante analisar a questão da competência para julgamento das contas de gestão de Alcaides sob o prisma prático, tendo em vista as dificuldades e os empecilhos de tal forma de controle externo.

Neste sentido foi o posicionamento das associações representativas das categorias de membros dos Tribunais de Contas (Atricon, Abracom e Audicon), dos membros do Ministério Público de Contas (Ampcon), dos Auditores de Controle Externo (ANTC) e de Servidores dos Tribunais de Contas do Brasil (FENASTC), os quais declararam em nota pública conjunta a perda da efetividade da Lei da Ficha Limpa, em razão das questões supracitadas, senão vejamos:

\begin{abstract}
O entendimento de todos os Tribunais de Contas do Brasil, do Tribunal Superior Eleitoral e do Ministério Público Federal, especialmente após o advento da Lei da Ficha Limpa, é de que os Prefeitos se submetem a duplo julgamento. Suas contas de governo - que têm um conteúdo limitado a aspectos contábeis, orçamentários, financeiros e fiscais - são julgadas pela Câmara de Vereadores, cabendo ao Tribunal de Contas, neste caso, a emissão de um Parecer Prévio, que somente pode ser rejeitado pelo Legislativo por decisão de $2 / 3$ dos Vereadores. Na hipótese, porém, em que o Prefeito decide assumir a atribuição de ordenador de despesas, os seus atos relativos ao processamento da despesa, integrarão, como as de quaisquer outros administradores de recursos públicos, as chamadas contas de gestão, cabendo o seu julgamento exclusivamente aos Tribunais de Contas, sem participação do Legislativo, conforme estabelece o artigo 71, II c/c artigo 75 da Constituição Federal.
\end{abstract}

Deste modo, cabe reiterar que o controle externo exercido pelo Legislativo Municipal tem caráter político e, por isso, muitas vezes deixa de lado o julgamento técnico atrelado a regras normativas e a critérios contábeis por razões eminentemente políticas. Certo que a presença de lideranças políticas populistas em muitos municípios e a concentração partidária 
amistosa em determinadas regiões tem como efeito julgamentos políticos ineficazes das contas de gestão.

Ademais, necessário salientar que, muitas vezes, a inércia das Câmaras Municipais traz danos à Administração Pública, bem como favorece a perpetuação de condutas ímprobas e corruptivas. Ora, como garantir o probo gerenciamento da coisa pública nos mais de cinco mil municípios brasileiros pelas Câmaras Municipais, certo que existem contas de Prefeitos que esperam há anos o julgamento político do órgão legislativo. Portanto, as decisões do Supremo Tribunal Federal contribuem para o aumento da demanda de julgamentos e análises políticas pela Poder Legislativo, o qual não nos parece o órgão com melhor aptidão técnica e estrutural para tanto.

Torna-se evidente que, em se tratando de questões técnicas e complexas, as Cortes de Contas pátrias possuem capacidade amplamente superior às Câmaras Legislativas para julgamento das contas públicas, em razão de seu corpo técnico e da formação dos Conselheiros que compõem o corpo julgador dos Tribunais de Contas, os quais contam com conhecimentos prévios em administração, contabilidade e gestão pública, além de ilibado conhecimento jurídico.

Como dito, os julgamentos e o controle externo exercido pelos Tribunais de Contas são feitos de forma técnica e especializada, tendo em vista os requisitos para assumir tal cargo previstos no Art. 73 da Constituição Federal, tais como ter mais de 35 anos e menos de 65, idoneidade moral, notórios saberes jurídicos, contábeis, econômicos, financeiros ou de administração pública, além de possuir mais de dez anos no exercício de função ou de efetiva atividade profissional que exija os conhecimentos supracitados.

Ademais, o processo de escolha dos membros que compõem as Cortes de Contas é complexo e envolve os Poderes Executivo e Legislativo, o que contribui para uma escolha técnica e democrática para o cargo, haja vista que os membros que compõem esses poderes são escolhidos por 
meio de eleição direta. Desse modo, a corrente que defende o argumento de que o julgamento pela Câmara Municipal representaria o desejo popular manifestado através de seus representantes não merece vigorar.

Há de se destacar que os movimentos sociais de insatisfação com o atual modelo político que ocorrem atualmente são decorrentes da insatisfação popular, em virtude das deflagrações de esquemas de corrupção e demais fiscalizações que demonstram e comprovam a prática de diversos atos de improbidade, principalmente pela classe política. Assim, tem-se que a população brasileira expressa avidez pela fiscalização e sancionamento, através de julgamentos técnicos, dos representantes que atuam gerindo o patrimônio público de forma ilegal e criminosa.

Assim, é sabido que mesmo auxiliando o Poder Legislativo no controle externo, os Tribunais de Contas, conforme Meirelles (2001), podem ser classificados como órgãos administrativos independentes, tal como é o Ministério Público. Desse modo, se estabelece uma relação de mútua cooperação entre as Cortes de Contas e o Poder Legislativo na fiscalização financeira e orçamentária descrita na Carta Magna. Evidencia-se, assim, a natureza jurídica de tais Tribunais como órgãos imprescindíveis ao controle externo por prestarem auxílio ao Poder Legislativo para o exercício de tais prerrogativas de controle, além de propiciarem uma análise técnica e livre de pressões externas ou de movimentos políticos mal intencionados.

Outrossim, é possível concluir que a decisão do Supremo Tribunal Federal suscita diversas implicações negativas no que tange a continuidade dos atos de improbidade administrativa cometidas pelos Prefeitos que agem como ordenadores de despesas. Ademais, a reafirmação das teses de Repercussão Geral n ${ }^{\circ} 157$ e n ${ }^{\circ} 835$ indicam a impunibilidade dos Prefeitos que provocam danos ao Erário, haja vista que o Tribunal de Contas não poderá aplicar diretamente multas de caráter sancionatório e, muito menos, imputar débito para que os prejuízos ao erário sejam restituídos e o gestor seja sancionado. 
Aliás, é justamente em tais casos de ilegalidades nas despesas e irregularidades das contas que restaria ao Tribunal de Contas atuar de forma sancionatória, aplicando penalidades através de acórdão próprio. Sabe-se que o papel da multa é o de punir o gestor por eventuais irregularidades e atos ímprobos que esse venha a cometer no exercício de suas funções, e a imputação de débito atua de forma reparadora dos desvios e desfalques de recursos do erário público, a fim de mitigar o dano causado à coisa pública. Desse modo, a impossibilidade de aplicação direta de multa e de imputação de débitos revelam-se como obstáculos ao exercício do papel sancionatório do Tribunal de Contas nos casos de gestão irregular, conforme preceitua a Constituição Federal no artigo $7^{\circ}$ nos incisos VIII, IX, X e XI.

Sendo assim, é possível concluir que a decisão do Supremo Tribunal Federal suscita diversas implicações negativas, gerando sérios óbices à realização de um controle externo mais efetivo e escorreito, visto que impossibilita que os Tribunais de Contas brasileiros julguem as contas de Alcaides que atuem na condição de ordenadores de despesas. De modo que a solução mais acertada nos parece a realização de interpretação conforme a constituição, no que diz respeito ao Art. 71, II, da CF/88, pelo Supremo Tribunal Federal, para que sejam declaradas as Cortes de Contas como os órgãos competentes para realizar o julgamento das contas de gestão de quaisquer gestor público, haja vista que esses são os únicos órgãos capazes de realizar julgamento técnico livre de pressões externas e movimentos políticos, concedendo efetividade ao controle externo e ao probo gerenciamento dos recursos públicos.

\section{CONSIDERAÇÕES FINAIS}

Mediante o elencado no desenvolvimento do presente artigo, empreende-se que a atuação dos Tribunais de Contas no exercício do controle externo técnico encontra-se nos normativos constitucionais da Carta Mag- 
na brasileira de 1988. Todavia, coexistem os debates e as problemáticas suscitadas por diversos doutrinadores e especialistas acerca da função julgadora e auxiliar dos Tribunais de Contas quanto às prestações de contas de gestão de Prefeitos que atuam como ordenadores de despesas.

Dessa forma, apesar das prerrogativas originárias do modelo moderno de controle externo existente nos Tribunais de Contas, conforme preconiza Rui Barbosa, deverá permanecer a atuação visando reverter e alertar as implicações dos referidos decisórios do Supremo Tribunal Federal nos Recursos Extraordinários $n^{\circ} 848.826, n^{\circ} 729.744$ e $n^{\circ} 1.231 .883$, haja vista o retrocesso causado aos valores republicanos e democráticos. Bem como, permanecerão as discussões teóricas e práticas sobre as implicações de tais decisórios da Corte Suprema ao controle externo brasileiro.

Em face disto, resta a problemática doutrinária e jurisprudencial, oriunda da análise do texto constitucional, acerca dos efeitos deletérios à Administração Pública e à sociedade em geral, do julgamento das contas de gestão de Prefeitos que atuam, conjuntamente, como ordenadores de despesas, visto que as recentes condenações sequentes de esquemas de corrupção deflagrados no país aumentaram o ensejo social pelo exercício independente e ativo do controle externo e pelo fortalecimento das Cortes de Contas no controle externo.

É sabido que a matéria reversada no presente artigo é complexa e requer maiores análises acerca das implicações negativas consubstanciadas por tais decisórios que obstam o pleno exercício das prerrogativas de controle externo pelos Tribunais de Contas. Sendo assim, faz-se necessária realizar a promoção de tais efeitos à sociedade, certo que a gestão da coisa pública deve ser de interesse geral da população brasileira. Logo, tem-se que tais decisórios com força impositiva não devem prosperar ao considerar o interesse público e o valor da atuação dos Tribunais de Contas para a preservação e escorreito funcionamento da máquina pública.

Portanto, é essencial reiterar a importância do julgamento dos Tribunais de Contas das contas de gestão de prefeitos ordenadores de despe- 
sas. Não devendo, pois, prevalecer o entendimento do mérito funcional do ordenador de despesas, mas, sim, a espécie de prestação de contas. Desse modo, fortalecer-se-á a atuação das Cortes de Contas na proteção do erário público contra gestores que praticam atos ímprobos e ilegais, em especial, no que tange o decidido monocraticamente até o presente momento no Recurso Extraordinário 1.231.883 do STF, o qual obsta a função sancionatória do Tribunal de Contas para imputar débitos e multar os gestores. Para isso, dever-se-á firmar entendimento acerca da temática considerando a espécie de contas prestadas e não o mérito funcional do ordenador.

Assim, o prefeito que atua como ordenador de despesas de pastas, fundos e/ou secretarias deve ser submetido também a julgamento pelos Tribunais de Contas. Faz-se necessária, portanto, a realização da revisão do entendimento da Suprema Corte para que seja realizada interpretação conforme a constituição, no que diz respeito ao Art. 71, II, da CF/88, pelo Supremo Tribunal Federal para que sejam declaradas as Cortes de Contas como os órgãos competentes para realizar o julgamento das contas de gestão de qualquer gestor público, haja vista que esses são os únicos órgãos capazes de realizar julgamento técnico, livre de pressões externas e movimentos políticos, concedendo efetividade à Lei Complementar $\mathrm{n}^{\mathrm{o}} .135$ de 2010 e o interesse público.

\section{REFERÊNCIAS}

AGUIAR, A. G.; AGUIAR, M. P. O tribunal de contas na ordem constitucional. Fortaleza: ABC, 2003.

ARISTÓTELES. A constituição de Atenas. São Paulo: Hucitec, 1995.

ATRICON. Resolução Atricon $\mathbf{n}^{\mathbf{0}}$ 1/2018, de 13 de agosto de 2018. Dispõe sobre as deliberações nos processos em que o Prefeito figura como ordenador de despesa. Brasília, DF: Atricon, 2018. Disponível em: https:// bit.ly/3nmsoeJ. Acesso em: 29 nov. 2020. 
ATRICON; ABRACOM; AUDICON; AMPCON; FENASTC; ANTC. Nota pública conjunta. Brasília, DF: Atricon, 2016. Disponível em: https://bit.ly/38FdMmE. Acesso em: 30 abr. 2020.

BRASIL. Constituição da República Federativa do Brasil de 1988. Brasília, DF: Senado Federal, 1988.

BRASIL. Decreto-Lei no 200, de 25 de fevereiro de 1967. Dispõe sobre a organização da Administração Federal, estabelece diretrizes para a Reforma Administrativa e dá outras providências. Diário Oficial da União, Brasília, DF, 27 fev. 1967. Disponível em: https://bit.ly/3poamdY. Acesso em 30 nov. 2020.

BRASIL. Lei Complementar n ${ }^{\circ} 64$, de 18 de maio de 1990. Estabelece, de acordo com o art. 14, $\S 9^{\circ}$ da Constituição Federal, casos de inelegibilidade, prazos de cessação, e determina outras providências. Diário Oficial da União, Brasília, DF, 21 maio 1990. Disponível em: https://bit.ly/3nqY82f. Acesso em: 30 abr. 2020.

BRASIL. Lei Complementar $\mathrm{n}^{\circ} 135$, de 4 de junho de 2010. Altera a Lei Complementar $\mathrm{n}^{\circ}$ 64, de 18 de maio de 1990, que estabelece, de acordo com o $\S 9^{\circ}$ do art. 14 da Constituição Federal, casos de inelegibilidade, prazos de cessação e determina outras providências, para incluir hipóteses de inelegibilidade que visam a proteger a probidade administrativa e a moralidade no exercício do mandato. Diário Oficial da União, Brasília, DF, 7 jun. 2010. Disponível em: https://bit.ly/35tGQeP. Acesso em: 30 abr. 2020 .

BRASIL. Lei $\mathrm{n}^{\circ} 8.443$, de 16 de julho de 1992. Dispõe sobre a Lei Orgânica do Tribunal de Contas da União e dá outras providências. Diário Oficial da União, Brasília, DF, 17 jul. 1992. Disponível em: https://bit. ly/31t8H4A. Acesso em: 30 jul. 2020. 
BRASIL. Supremo Tribunal Federal. Recurso Especial no 729.744. Brasília, DF: STF, 2013. Disponível em: https://bit.ly/2ICuM2d. Acesso em: 30 abr. 2020.

BRASIL. Supremo Tribunal Federal. Recurso Especial $\mathbf{n}^{\circ}$ 848.826. Brasília, DF: STF, 2014. Disponível em: https://bit.ly/3nj9OUX. Acesso em: 30 abr. 2020.

BRASIL. Supremo Tribunal Federal. Recurso Especial $\mathbf{n}^{0}$ 1.231.883. Brasília, DF: STF, 2019. Disponível em: https://bit.ly/3pkYFoi. Acesso em: 30 abr. 2020.

CEARÁ. Lei $\mathrm{n}^{\circ} 12.509$, de 6 de dezembro de 1995. Dispõe sobre a Lei Orgânica do Tribunal de Contas do Estado do Ceará e dá outras providências. Diário Oficial do Estado do Ceará, Fortaleza, 6 dez. 1995. Disponível em: https://bit.ly/2GXQWLx. Acesso em: 29 jul. 2020.

CEARÁ. Tribunal de Contas do Estado do Ceará. Acórdão no 691/18. Fortaleza: TCE-CE, 2018. Disponível em: https://bit.ly/32HQpFr. Acesso em: 30 abr. 2020.

COSTA, L. B. D. Tribunal de contas: evolução e principais atribuições no Estado democrático de direito. Belo Horizonte: Fórum, 2006.

FERNANDES, F. S. O Tribunal de Contas e a fiscalização municipal. Revista do Tribunal de Contas do Estado de São Paulo, São Paulo, n. 65, 1991.

FURTADO, J. R. C. O regime de contas públicas: contas de governo e contas de gestão. Revista Interesse Público, Porto Alegre, n. 42, 2007. 
JACOBY, J. U. F. Da função jurisdicional pelos Tribunais de Contas. Revista Brasileira de Direito Público, Belo Horizonte, n. 9, p. 83-108, 2005.

JACOBY, J. U. F. Tribunais de Contas do Brasil: jurisdição e competência. Belo Horizonte: Fórum, 2012.

LIMA, L. H. Controle externo: teoria e jurisprudência para os tribunais de contas. 8. ed. São Paulo: Método, 2019.

MATA, M. F. O. Fiscalização da administração pública em face da economicidade. Revista dos Tribunais, São Paulo, n. 710, p. 233-236, 1994.

MEIRELLES, H. L. Direito administrativo brasileiro. 32. ed. São Paulo: Malheiros, 2006.

MEIRELLES, H. L. Direito municipal brasileiro. 12. ed. São Paulo: Malheiros, 2001.

MELLO, C. A. B. Curso de direito administrativo. 24. Ed. São Paulo: Malheiros, 2005.

MELlO, C. A. B. Funções do Tribunal de Contas. Revista de Direito Público, n. 72, 1984.

NUNES, M. B. Contas de governo e contas de gestão. Revista Téenica dos Tribunais de Contas, Belo Horizonte, n. 1, 2011.

PASCOAL, V. F. Direito financeiro e controle externo. São Paulo: Método, 2015. 
PINTO, D. Elegibilidade no direito brasileiro. São Paulo: Atlas, 2008.

SILVA, E. R.; BELLAN, R. A. A dupla função do Tribunal de Contas na fiscalização das contas do Prefeito Municipal. Revista Técnica dos Tribunais de Contas, Belo Horizonte, n. 1, 2011.

SILVA, J. A. Curso de direito constitucional positivo. 24. ed. São Paulo: Malheiros, 2004. 